\title{
PENGUATAN EKONOMI MASYARAKAT BERBASIS KELOMPOK
}

\author{
Mochamad Ridwan \\ Fakultas Ekonomi Universitas Bengkulu \\ Jalan WR. Supratman Bengkulu Indonesia \\ E -mail: mochamadridwan61@gmail.com
}

Diterima 19 Desember 2011 / Disetujui 13 Agustus 2012

\begin{abstract}
This study aims to make a synthesis related to efforts to develop an alternative modeling of the process of strengthening (empowering) the economy of poor coastal communities through the optimization of the group's role as the basis for economic development towards greater prosperity. Two programs of empowerment that are assessed Coastal Community Economic Empowerment Program and Program of Revenue Improvement for Small Farmers and Fishermen. To analyze the data has been collected, used four methods: Multiple Linear Regression Method, Path analysis, Structural Equation Model, and Descriptive Method (What-If Analysis). The results showed that alternative models that have been synthesized assume important roles in the group as a strategic base on the effectiveness of the program, besides the influence of internal and external factors, which are both strongly associated with quality resources and local knowledge of each area/coastal areas where the coastal areas tend to one another there is a difference.
\end{abstract}

Keywords: alternative model, economic empowerment, the base group, the welfare of coastal communities

\begin{abstract}
Abstrak: Penelitian ini bertujuan melakukan sintesis berkaitan dengan upaya menyusun sebuah model alternatif proses pemberdayaan ekonomi masyarakat miskin pesisir melalui optimalisasi peran kelompok sebagai basis pengembangan ekonomi ke arah peningkatan kesejahteraan. Dua program pemberdayaan yang dikaji adalah Program Pemberdayaan Ekonomi Masyarakat Pesisir dan Program Peningkatan Pendapatan Petani-Nelayan Kecil. Untuk menganalisis data yang telah diperoleh, digunakan Metode Regresi Linear Berganda, Metode Path analysis, Metode Analisis Model Persamaan Struktural, dan Metode Deskriptif (Analisis What-If). Hasil penelitian menunjukkan bahwa model alternatif yang dapat disintesiskan menganggap penting peran kelompok sebagai basis strategis dalam pengefektifan pelaksanaan program, di samping memperhatikan pengaruh faktor internal dan eksternal, yang sangat terkait dengan kualitas sumber daya dan kearifan lokal dari masing-masing daerah pesisir, di mana antara wilayah pesisir satu dengan yang lain cenderung terdapat perbedaan.
\end{abstract}

Kata kunci: model alternatif, pemberdayaan ekonomi, basis kelompok, kesejahteraan masyarakat pesisir

\section{PENDAHULUAN}

Kemiskinan merupakan gambaran dari sebuah fenomena dan permasalahan sosial yang terjadi di masyarakat, dengan bentuk yang komplek dan multidimensional. Data statistik (BPS, 2010) menunjukkan bahwa sampai dengan tahun 2010, penduduk Indonesia berjumlah sekitar
237.641 juta jiwa, sebagian besar hidup di bawah garis kemiskinan (poverty line) atau dengan kata lain tingkat kesejahteraan mereka sangat memprihatinkan. Penduduk miskin yang hidup di perdesaan tersebut, sebagian bertempat tinggal di wilayah pesisir dan bekerja sebagai nelayan.

Dilihat dari tingkat keberdayaannya, kondisi masyarakat pesisir (masyarakat nelayan) 
sebagian besar masih dikategorikan ke dalam kelompok nelayan tradisional (nelayan kecil). Dibandingkan dengan komunitas lain, masyarakat pesisir/masyarakat nelayan masih tergolong lapisan sosial "termiskin" (Mubyarto dkk., 1993; Soesilo dan Budiman, 2002).

Berbagai kebijakan pemerintah berkaitan dengan pemberdayaan ekonomi masyarakat telah digulirkan (Program IDT, Program PKS, Program PEMP, dan lain-lain), namun hasilnya sebagian besar belum berjalan efektif atau belum sesuai dengan yang diharapkan (Sumodiningrat, 1996; Saefuddin, $d k k ., 2003)$.

Saefuddin, $d k k$. (2003) menunjukkan bahwa dalam proses pelaksanaan di lapangan, ketidakefektifan penerapan program pemberdayaan ekonomi bagi masyarakat miskin, pada umumnya disebabkan oleh beberapa faktor yaitu: (1) rendahnya tingkat kejujuran dari sebagian pelaksana/pengelola program dan penerima dana bantuan (beneficiaries), (2) lemahnya tingkat koordinasi dan kerjasama, dan (3) Modal sosial/partisipasi masyarakat (dukungan moral) masih bersifat semu (Yustika, 2006).

Berbagai teori telah menjelaskan hubungan kausalitas proses terjadinya kemiskinan dan mengapa pemberdayaan ekonomi masyarakat miskin harus dilakukan. Beberapa teori kemiskinan (teori lingkaran kemiskinan, teori budaya kemiskinan, dan beberapa teori kemiskinan lainnya) mengungkap penyebab kemiskinan baik dari faktor-faktor eksternal (seperti ketidak sempurnaan pasar, akses modal yang rendah, dan lain-lain) maupun faktor-faktor internal (seperti tingkat pendidikan yang rendah, tatanilai budaya, dan lain-lain).

Di dalam konteks kesejahteraan masyarakat, beberapa teori seperti teori ekonomi kesejahteraan, teori ekspektasi, teori motivasi, dan teori Y menjelaskan: (1) secara substansial, kesejahteraan masyarakat dipengaruhi oleh faktor eksternal seperti lingkungan yang ada di sekitar masyarakat miskin dan intervensi pemerintah dan beberapa faktor internal (faktor demografis) seperti tingkat pendidikan, kemampuan kerja, motivasi kerja, kinerja, pengalaman kerja, dan karakteristik individual; (2) perubahan kesejahteraan masyarakat ke arah lebih baik atau lebih tinggi merupakan tujuan utama dari implementasi program peningkatan kesejahteraan masyarakat.

Kerangka dasar teoritik berkaitan dengan permasalahan penelitian, terbagi ke dalam dua penjelasan, yaitu:

(1) Kerangka dasar teoritik berkaitan dengan interaksi antarvariabel-variabel penentu: Berdasar pada teori-teori yang mendukungnya, faktor-faktor penyebab ketidakefektifan terbentuk ke dalam sebuah hubungan kausalitas atau hubungan pengaruh antarfaktor-faktor yang terlibat dalam sistem.

Hubungan kausalitas ini mencakup variabel-variabel komitmen pengelola, modal sosial (dukungan moral dari masyarakat pengguna, yang tercermin dari tingkat kepercayaan antar anggota dalam kelompok), tingkat kesesuaian antara yang diajukan dengan realisasi, pendapatan masyarakat pesisir, manfaat keberadaan kelompok, dan karakteristik kelembagaan.

(2) Kerangka dasar teoritik berkaitan dengan perbandingan antardua program yang sudah ada sebelumnya: Didasarkan pada pemikiran logis bahwa satu hasil (output) yang dianggap terbaik, tidak mungkin akan diperoleh tanpa adanya perbandingan antardua program yang mempunyai maksud dan tujuan, atau visi dan misi yang sama/sejalan.

Metode perbandingan/komparasi antardua program yang digunakan dapat dapat untuk mengidentifikasi kelebihan dan kekurangan masing-masing program.

\section{METODE PENELITIAN}

Pendekatan yang digunakan dalam penelitian ini adalah pendekatan bauran (mix-approach), yang dilakukan dengan menggabungkan pendekatan kuantitatif dan pendekatan kualitatif sebagai pendukungnya.

Dua wilayah pesisir yang dipilih sebagai wilayah penelitian adalah kabupaten Malang dan kabupaten Pasuruan, di mana keduanya berada di provinsi Jawa Timur.

Populasi target dari penelitian ini adalah semua rumah tangga (RT) yang mendapatkan manfaat dari Program PEMP atau P4K, berasal dari masyarakat pesisir, baik yang ada di 
wilayah kabupaten Malang maupun kabupaten Pasuruan.

Metode pengambilan sampel secara "acak sederhana" (simple random sampling) digunakan dalam penelitian ini, maka 178 rumah tangga diambil untuk dijadikan sampel penelitian (sekaligus sebagai responden pada proses penelitian). Di samping itu diambil 17 orang yang berasal dari pengelola dan 17 orang berasal dari tokoh masyarakat serta mereka yang dianggap telah berhasil sebagai key-informan.

Jenis data yang dikumpulkan dari penelitian adalah data kualitatif dan data kuantitatif, yang terdiri dari: data primer, data sekunder, dan data yang bersumber dari hasil dokumentasi (fotografi), hasil rekaman kaset (cassette recording), dan hasil rekaman video (video recording).

Data penelitian dikumpulkan melalui beberapa teknik/metode yaitu: metode wawancara mendalam (in-depth interview), kuesioner/ angket, observasi, diskusi kelompok terfokus (Focus Group Discussion/FGD), dan dokumentasi.

Dua bentuk metode analisis yang digunakan dalam penelitian ini adalah metode analisis kuantitatif, yang didukung oleh analisis kualitatif.

Data kuantitatif yang telah didapatkan dianalisis melalui metode/teknik analisis Regresi Linear Berganda dan metode/teknik analisis Model Persamaan Struktural (Structural Equation Modeling/SEM). Sedangkan data kualitatif yang diperoleh, selanjutnya dianalisis melalui metode analisis deskriptif (analisis WhatIf).

\section{HASIL DAN PEMBAHASAN}

Melalui uji $\mathrm{t}$ ( $\mathrm{t}$ test), hasil perhitungan memperlihatkan nilai-nilai koefisien regresi, baik berasal dari unstandardized coefficients $(\beta)$ maupun dari standardized coefficients $(\beta)$.

Dalam konteks analisis hasil penelitian, interpretasi koefisien regresi yang digunakan adalah Standardized coefficients $(\beta)$.

Hasil perhitungan menunjukkan bahwa dari variabel-variabel independen yang terlibat (N1, ..., N5, dan N6), hanya variabel N4
(Karakteristik kelembagaan) saja yang nilainya tidak signifikan walaupun pada $a=0,10$ atau $10 \%$.

Oleh karena koefisien regresi yang distandardisasikan pada dasarnya sama dengan nilai dari koefisien lintas, maka persamaan regresinya dapat diwujudkan dalam sebuah persamaan sub-struktural sebagai berikut:

$$
\begin{aligned}
\mathrm{N} 1= & 0,591 \mathrm{Q} 5 \\
\mathrm{~N} 2= & 0,696 \mathrm{~N} 6 \\
\mathrm{M}= & 0,501 \mathrm{~N} 1+0,303 \mathrm{~N} 2+0,203 \mathrm{~N} 3+ \\
& 0,043 \mathrm{~N} 4^{*}
\end{aligned}
$$

Keterangan: * $\mathrm{N} 4 \rightarrow$ tidak signifikan

Berdasarkan tiga persamaan di atas, kemudian dibuat diagram lintas (path diagram) yang menunjukkan pengaruh langsung antarvariabel, sebagai berikut:



Keterangan: * : N4 $\rightarrow$ tidak signifikan

\section{Gambar 1. Diagram Lintas 1}

Dari Gambar 1 dapat dilakukan interpretasi sebagai berikut:

(1) Koefisien regresi yang distandardisasi- 
kan untuk N6 memberikan nilai sebesar 0,696 untuk pengaruhnya secara langsung terhadap N2 (Pendapatan nelayan). Pengaruh positif dari N6 (Kesesuaian antara jumlah pengajuan dan realisasi) ini mempunyai makna semakin sesuai jumlah pinjaman yang diajukan dengan realisasi, pengaruh terhadap peningkatan kelancaran angsuran akan semakin tinggi, yang disebabkan semakin membaiknya pendapatan yang diterima oleh nelayan.

(2) Koefisien regresi yang distandardisasikan dari N2 sebesar 0,303, yang signifikan pada $a=5 \%$. Hubungan kausalitas ini secara kualitatif diperkuat oleh hasil hasil penelitian melalui wawancara dengan masyarakat pemanfaat program (beneficiaries) yang sebagian besar berpendapat bahwa ketidaklancaran pembayaran angsuran tersebut sebenarnya dipicu oleh ketidaksesuaian antara jumlah yang diajukan atau yang diharapkan diterima dengan realisasinya.

(3) Koefisien regresi yang distandardisasikan untuk N5 (Komitmen pengelola) memberikan nilai sebesar 0,591 dalam pengaruhnya secara langsung terhadap N1 (Dukungan moral dari nelayan), yang signifikan pada tingkat signifikansi $(\alpha)=0,05$ atau $5 \%$. Pengaruh positif N5 (Komitmen pengelola program) terhadap N1 (Dukungan moral) mempunyai makna semakin tinggi komitmen pengelola program terhadap masyarakat pemanfaat program (beneficiaries), dukungan moral cenderung semakin tinggi. Semakin tinggi modal sosial (dukungan moral) akan berdampak kepada semakin tingginya tingkat kelancaran pembayaran angsuran, yang dicerminkan oleh nilai koefisien regresi yang distandardisasikan sebesar 0,501 dan signifikan pada $a=5 \%$. Kesimpulan ini diperjelas oleh hasil penelitian yang menunjukkan bahwa dari dukungan moral yang tinggi dari kelompok masyarakat pemanfaat, yang ditampakkan oleh tingginya kesadaran masyarakat membayar angsurannya ke ketua kelompoknya atau ke mitra desanya masing-masing, pada umumnya kemacetan tidak terjadi. Sebaliknya jika para ketua kelompok atau para mitra desanya cenderung melakukan sendiri pengambilan angsuran ke masing-masing anggota kelompoknya atau dari rumah ke rumah. Model pengambilan angsuran dari rumah ke rumah ini dalam prakteknya sulit untuk dijalankan dan bahkan lambat laun telah menimbulkan kejenuhan dari pihak ketua kelompok atau para mitra desa itu sendiri, yang pada akhirnya berujung ke arah terjadinya kemacetan angsuran.

(4) Koefisien regresi yang distandardisasikan untuk N3 (Manfaat keberadaan kelompok pemanfaat) memberikan nilai sebesar 0,203, yang signifikan pada tingkat signifikansi (a) 0,05 atau $5 \%$. Nilai ini menunjukkan dalam uji statistik ternyata N3 (Manfaat keberadaan kelompok pemanfaat) berpengaruh secara signifikan terhadap M (Tingkat kelancaran angsuran). Dalam pengertian lain, semakin baik fungsi dari keberadaan kelompok pemanfaat, tingkat kelancaran angsuran pinjaman akan semakin tinggi. Pengaruh N3 (Manfaat keberadaan kelompok pemanfaat) terhadap M (Tingkat kelancaran angsuran) ini diperkuat oleh hasil pengamatan terhadap beberapa sasaran program, yang menunjukkan bahwa pada daerah/desa yang keberadaan kelompok pemanfaatnya berfungsi dengan baik, secara umum tingkat kelancaran angsuran lebih tinggi dari daerah/ desa yang keberadaan kelompok pemanfaatnya kurang berfungsi dengan baik. Hasil analisis ini secara tidak langsung telah memperkuat konsep program itu sendiri yang menganggap keberadaan kelompok mempunyai peranan yang sangat strategis pada efektivitas penerapan program khususnya berkaitan dengan masalah peningkatan kelancaran angsuran pinjaman (secara tidak langsung berkaitan dengan upaya meningkatkan efektivitas perguliran dana/revolving funds.

(5) Koefisien regresi yang distandardisasikan untuk N4 (Karakteristik kelembagaan) memberikan nilai sebesar 0,043, yang tidak signifikan pada tingkat signifikansi $(a)=5 \%$ dan pada tingkat signifikansi $(\alpha)=10 \%$. Nilai ini menunjukkan bahwa dalam uji statistik ternyata N4 (Karakteristik kelembagaan) tidak berpengaruh terhadap $M$ (Tingkat kelancaran angsuran). Tidak berpengaruhnya N4 (Karakteristik kelembagaan) terhadap M (Tingkat kelancaran angsuran) ini dapat dijelaskan melalui hasil penelitian yang memperlihatkan bahwa sejak awal pelaksanaan program, berbagai bentuk penerapan jaminan/agunan pada bantuan pinjaman, pemberian sanksi, dan tingkat bunga 
pinjaman (ketiganya merupakan cerminan dari karakteristik kelembagaan), ternyata hanya tingkat bunga pinjaman saja yang bisa diterapkan secara efektif. Sedangkan pada penerapan sanksi pelanggaran kesepakatan peminjaman dan jaminan atau agunan, keduanya tidak bisa diterapkan secara efektif. Hal ini karena terkendala oleh kemungkinan adanya faktorfaktor lain yang sebenarnya pengaruhnya cukup signifikan tetapi tidak dimasukkan ke dalam sistem atau persamaan yang sudah ada. Hasil penelitian memperlihatkan adanya pendapat masyarakat yang menyatakan banyaknya hasutan/provokasi berupa ajakan untuk tidak melakukan pembayaran angsuran. Mereka beranggapan bahwa bantuan program adalah sebagai pemberian atau hadiah (charity) dari pemerintah kepada masyarakat miskin nelayan. Anggapan (image) semacam inilah yang memungkinkan tidak berfungsinya sanksi untuk dapat diterapkan secara tegas. Di samping itu, tidak diterapkannya fungsi jaminan/agunan pada pelaksanaan program, menyebabkan tidak berpengaruhnya N4 (Karakteristik kelembagaan) terhadap $\mathrm{M}$ (Tingkat kelancaran angsuran). Uraian hasil penelitian yang bersifat kualitatif tersebut sebenarnya dapat memperkuat alasan mengapa N4 (Karakteristik kelembagaan) tidak mampu menjelaskan variabilitas M (Tingkat kelancaran angsuran) atau tidak mempunyai pengaruh secara signifikan kendatipun sampai tingkat signifikansi (a) sebesar $10 \%$.

(6) Koefisien regresi yang distandardisasikan untuk N6 memberikan nilai sebesar 0,696 untuk pengaruhnya secara langsung terhadap N2 (Pendapatan nelayan). Besarnya nilai ini mempunyai arti penting bahwa variabel N6 (Kesesuaian antara jumlah pengajuan dan realisasi) mempunyai pengaruh positif paling kuat diantara variabel-variabel yang lain yang signifikan pada tingkat signifikansi (a) 0.05 atau 5\% yaitu terhadap N2 (Pendapatan nelayan). Pengaruh positif dari N6 (Kesesuaian antara jumlah pengajuan dan realisasi) mempunyai makna semakin sesuai jumlah pinjaman yang diajukan dengan realisasi, pembayaran angsuran akan semakin lancar disebabkan semakin membaiknya pendapatan yang diterima oleh nelayan. Hal ini berdasarkan pada pengaruh langsung yang dilihat dari nilai koefisien regresi yang distandardisasikan dari N6 (Kesesuaian antara jumlah pengajuan dan realisasi) terhadap M (Tingkat kelancaran angsuran) lebih kecil dari pada pengaruh tidak langsungnya melewati N2 (Pendapatan nelayan). Perlu dipertimbangkan di sini bahwa pengaruh langsung dari N2 terhadap M yakni sebesar 0,173 ternyata nilainya lebih kecil bila dibandingkan dengan pengaruh langsung dari N6 terhadap $M$, yang memungkinkan pengaruh $N 2$ terhadap $M$ tersebut dikalahkan oleh pengaruh N6 terhadap M. Kesimpulan ini diperjelas oleh hasil penelitian yang menunjukkan bahwa dari masyarakat pemanfaat program (beneficiaries) yang telah mendapat bantuan dana pinjaman sebagian besar berpendapat bahwa ketidakmampuan melakukan pembayaran angsuran tersebut disebabkan karena rasa ketidak puasan dari ketidak sesuaian antara jumlah yang diajukan atau yang diharapkan diterima dengan realisasinya. Karena faktor ketidaksesuaian inilah yang mengakibatkan terjadinya pelencengan kegunaan dari yang direncanakan semula atau terjadinya salah pengelolaan (mismanagement), sehingga modal usaha tidak jadi berkembang dan kondisi pendapatan nelayan tidak bertambah baik, yang pada akhirnya berdampak negatif terjadinya ketidak lancaran bahkan kemacetan pembayaran angsuran.

Sesuai dengan paradigma hubungan antar variabel yakni dalam bentuk hubungan struktural, hasil perhitungan memberikan susunan lima model matematik persamaan struktural, yaitu:

(1) $\mathrm{KARKTIND}=\beta 1$ PENGKER $+\varepsilon 1$

(2) KEMAKER $=\beta 2$ PEMP $+\beta 3$ PDDKN $+\varepsilon 2$

(3) MOTKER $=\beta 4$ KARKTIND $+\beta 5$ LINGKER $+\beta 6$ KEMAKER $+\varepsilon 3$

(4) KINERJA $=\beta 7$ MOTKER $+\beta 8$ KEMAKER + $\varepsilon 4$

(5) $\mathrm{KESEJTR}=\beta 9$ KINERJA $+\varepsilon 5$

Didasarkan pada hasil komputerisasi (dengan program aplikasi SmartPLS) diperoleh hasil dalam bentuk diagram lintas/diagram jalur sebagai berikut: 


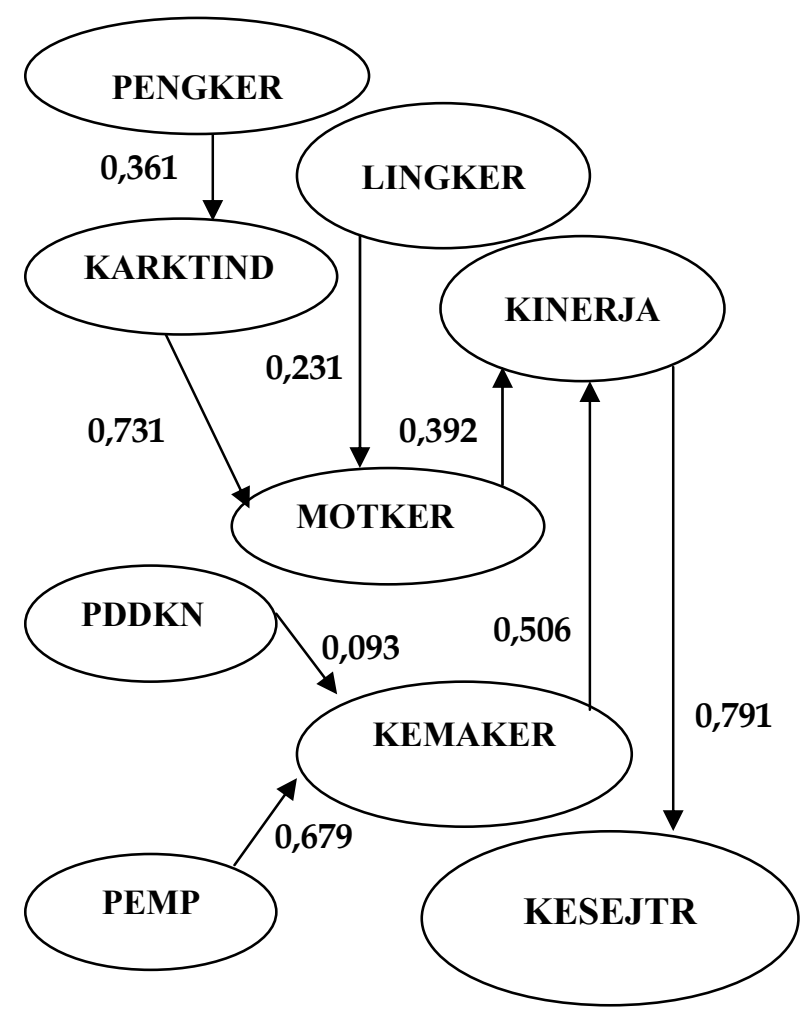

Gambar 2. Diagram Lintas 2

Keterangan:

KESEJTR: Kesejahteraan nelayan

Y1 adalah Penghasilan/pendapatan nelayan, Y2 adalah Status pekeraan nelayan, Y3 adalah Aset/kekayaan rumah tangga nelayan,

KINERJA: Kinerja nelayan

X16 adalah Nilai hasil kerja nelayan

MOTKER: Motivasi Kerja nelayan

X13 adalah Jam kerja nelayan, X14 adalah Strategi kerja nelayan, X15 adalah Keberanian kerja nelayan

KEMAKER: Kemampuan Kerja Nelayan

X4 adalah Modal nelayan, X5 adalah Inovasi kerja nelayan

\section{KARKTIND: Karakteristik Individual}

X6 adalah Keseriusan/kerajinan kerja nelayan

LINGKER: Lingkungan Kerja Nelayan

X7 adalah Lembaga ekonomi nelayan, X12 adalah Keamanan kerja nelayan

PENGKER: Pengalaman Kerja Nelayan

X3 adalah Lama masa kerja nelayan

PDDKN: Pendidikan

X2 adalah Tingkat pendidikan nelayan

PEMP: Program PEMP

X1 adalah Kucuran dana Program dari PEMP

Dari diagram lintas di atas, selanjutnya dapat dituliskan dalam bentuk model persamaan strukturalnya sebagai berikut:

(1) KARKTIND $=0$ 0,361 PENGKER

(2) KEMAKER $=0,678$ PEMP + 0,093 PDDKN

(3) MOTKER $=0,555$ KARKTIND + 0,182

LINGKER + 0,272 KEMAKER

(4) KINERJA $=0,389$ MOTKER $+0,509$

KEMAKER

(5) KESEJTR $=0$,791 KINERJA

Pada Gambar 2 tampak bahwa didasarkan pada konstruk-konstruk yang terbentuk, terdapat satu konstruk yang indikatornya merupakan "indikator formatif" yakni konstruk LINKER (Lingkungan Kerja Nelayan). Konstruk-konstruk yang lain merupakan konstruk dengan "indikator refleksif" yakni KESEJTR (Kesejahteraan Nelayan), KINERJA (Kinerja Nelayan), MOTKER (Motivasi Kerja Nelayan), KEMAKER (Kemampuan Kerja Nelayan), KARKTIND (Karakteristik Individual Nelayan), PENGKER (Pengalaman Kerja Nelayan), PDDKN (Pendidikan Nelayan) dan PEMP (Program PEMP untuk Nelayan).

Hasil perhitungan komputerisasi menunjukkan konstruk-konstruk yang mempunyai indikator refleksif adalah KEMAKER (Kemampuan Kerja Nelayan), MOTKER (Motivasi Kerja Nelayan), KINERJA (Kinerja Nelayan), KARKTIND (Karakteristik Individual Nelayan), PENGKER (Pengalaman Kerja Nelayan), PDDKN (Pendidikan Nelayan), PEMP (Program PEMP), dan KESEJTR (kesejahteraan Nelayan); semuanya menunjukkan "reliabilitas" sangat tinggi. Hal ini ditunjukkan oleh nilainilai baik dari composite reliability maupun dari Average Variance Extracted (AVE) sangat tinggi.

Pada sisi lain, hasil perhitungan komputerisasi menunjukkan bahwa dengan melihat covergent validity masing-masing indikator yakni berdasarkan nilai loading factor, semua indikator dari semua konstruk yang mempunyai indikator refleksif tersebut adalah cukup tinggi (melebihi dari yang dipersyaratkan yaitu lebih besar dari 0,70). Tingginya nilai dari semua indikator, membuktikan bahwa semua indikator refleksif menunjukkan validitas yang tinggi. 
Oleh karena konstruk dengan indikator formatif pada dasarnya merupakan hubungan regresi dari indikator ke konstruk, maka cara menilainya adalah dengan melihat nilai koefisien regresi dan signifikansi dari koefisien regresi tersebut. Dengan kata lain, validitas dari masing-masing indikator pembentuk konstruk dapat dilihat dari nilai "weight" dari masingmasing indikator dan nilai signifikansinya.

Hasil perhitungan komputerisasi menunjukkan bahwa dari keenam indikartor formatif yang dianggap bisa mengukur konstruk LINGKER (Lingkungan Kerja Nelayan), ternyata hanya pada indikator-indikator formatif X7 dan $\mathrm{X} 12$ saja yang nilainya signifikan dan melebihi dari yang disyaratkan yakni lebih dari nilai $\mathrm{T}$ Tabel sebesar 1,96 pada tingkat signifikansi (a) 0,05 atau $5 \%$. Sehingga hanya indikator X7 dan X12 saja adalah "cukup valid" untuk mengukur konstruk LINGKER (Lingkungan Kerja Nelayan) dan sisanya dinyatakan tidak valid. Hasil perhitungan komputerisasi membantu mengungkapkan hubungan kausalitas atau pengaruh beserta tingkat signifikansinya dan sekaligus hasil uji hipotesis dari beberapa hubungan kausalitas atau pengaruh antara konstruk satu dengan konstruk yang lain, yaitu:

(1) Hubungan kausalitas berbentuk pengaruh dari konstruk PENGKER (Pengalaman Kerja Nelayan) terhadap konstruk KARKTIND (Karakateristik Individual Nelayan) memberikan nilai koefisien jalur/lintas atau nilai estimasi parameter (Original Sample Estimate) sebesar 0,361 dan signifikan pada tingkat signifikansi (a) 0,05 atau $5 \%$.

(2) Hubungan kausalitas berbetuk pengaruh dari konstruk PEMP (Kucuran dana dari Program PEMP untuk Nelayan) terhadap konstruk KEMAKER (Kemampuan Kerja Nelayan) memberikan nilai koefisien jalur/lintas atau nilai estimasi parameter (Original Sample Estimate) sebesar 0,679 dan signifikan pada tingkat signifikansi (a) 0,05 atau 5\%.

(3) Hubungan kausalitas berbetuk pengaruh dari konstruk PDDKN (Pendidikan dan Pelatihan Nelayan) terhadap konstruk KEMAKER (Kemampuan Kerja Nelayan) memberikan nilai koefisien jalur/lintas atau nilai estimasi parameter (Original Sample Estimate) sebesar 0,093 dan tidak signifikan pada tingkat signifikansi (a) 0,05 atau $5 \%$.

(4) Hubungan kausalitas berbetuk pengaruh dari konstruk LINGKER (Linglkungan Kerja Nelayan) terhadap konstruk MOTKER (Motivasi Kerja Nelayan) memberikan nilai koefisien jalur/lintas atau nilai estimasi parameter (Original Sample Estimate) sebesar 0,231 dan signifikan pada tingkat signifikansi (a) 0,05 atau 5\%.

(5) Hubungan kausalitas berbentuk pengaruh dari konstruk KARKTIND (karakteristik Individual Nelayan) terhadap konstruk MOTKER (Motivasi Kerja Nelayan) memberikan nilai koefisien jalur/lintas atau nilai estimasi parameter (Original Sample Estimate) sebesar 0,731 dan signifikan pada tingkat signifikansi (a) 0,05 atau $5 \%$.

(6) Hubungan kausalitas berbentuk pengaruh dari konstruk KEMAKER (Kemampuan Kerja Nelayan) terhadap konstruk KINERJA (Kinerja Nelayan) memberikan nilai koefisien jalur/lintas atau nilai estimasi parameter (Original Sample Estimate) sebesar 0,506 dan signifikan pada tingkat signifikansi (a) 0,05 atau 5\%.

(7) Hubungan kausalitas berbentuk pengaruh dari konstruk MOTKER (Motivasi Kerja Nelayan) terhadap konstruk KINERJA (Kinerja Nelayan) memberikan nilai koefisien jalur/ lintas atau nilai estimasi parameter (Original Sample Estimate) sebesar 0,392 dan signifikan pada tingkat signifikansi (a) 0,05 atau 5\%.

(8) Hubungan kausalitas berbetuk pengaruh dari konstruk KINERJA (Kinerja Nelayan) terhadap konstruk KESEJTR (Kesejahteraan Nelayan) memberikan nilai koefisien jalur/ lintas atau nilai estimasi parameter (Original Sample Estimate) sebesar 0,791 dan signifikan pada tingkat signifikansi (a) 0,05 atau 5\%.

(9) Di antara sembilan hubungan kausalitas antara konstruk satu dengan yang lain, ternyata hanya satu konstruk yang pengaruhnya tidak signifikan yaitu hubungan kausalitas dari konstruk PDDKN (Pendidikan nelayan) terhadap konstruk KEMAKER (Kemampuan Kerja Nelayan).

Komparasi/Perbandingan antardua program berkaitan dengan solusi berbagai permasalahan yang terjadi dari penerapan program (Program PEMP dan P4K): 
Dikaitkan dengan penerapan dua program (Program PEMP dan P4K), melalui analisis deskriptif kualitatif (analisis "What-If") diperoleh informasi sebagai berikut:

(1) Dilihat dari jawaban pengelola dan pengguna/pemanfaat program, secara umum mereka menyetujui pentingnya menjaga kelancaran perguliran dana (revolving) agar distribusi bantuan pinjaman dapat bergulir secara lebih merata.

(2) Untuk mengatasi ketidaklancaran dalam perguliran dana (revolving), dari pihak pengelola program cenderung: (a) sebagian besar setuju dengan mengupayakan agar tidak terjadi kemacetan di tingkat kelompok pemanfaat, (b) tindakan yang dilakukan jika terjadi kemacetan adalah dengan melakukan pembinaan secara kontinu "rescheduling" (penjadwalan ulang), dan (c) strategi yang dilakukan adalah pengembangan tabungan individu atau kelompok, guna mengatasi kemacetan salah satu anggota kelompok (karena didasarkan aturan angsuran peminjaman bersifat "tanggung renteng").

(3) Pihak pemanfaat memiliki beberapa kecenderungan pendapat: (a) keseluruhan responden setuju untuk berusaha menghindari terjadinya kemacetan, karena akan berdampak tidak adanya tambahan modal pinjaman, (b) sebagian besar berpendapat bahwa kemacetan dalam kelompok dapat diatasi dengan pembinaan secara kontinu dari pihak pengelola, misalnya dengan pendampingan oleh PPL.

(4) Berkaitan dengan peran pengelola program, terdapat berbagai kecenderungan bentuk jawaban: (a) Pihak pengelola PEMP/P4K; keseluruhan responden berpendapat bahwa keberadaan pengelola program (Program PEMP/ P4K), TPD, Konsultan Manajemen, dan PPL sangat urgen (sangat dibutuhkan), karena peranannya dalam pembinaan dan pengontrolan terhadap pelaksanaan program. (b) Pihak pemanfaat program (beneficiaries) pada umumnya berpendapat bahwa keberadaan pengelola program sangat dibutuhkan, kecuali terhadap keberadaan konsultan manajemen. Sebagian besar dari mereka berpendapat bahwa keberadaan konsultan manajemen dianggap tidak penting karena tidak pernah berkecimpung di lapangan.

(5) Berkaitan dengan peranan sistem perekrutan/penyeleksian terhadap penerima program, terdapat beberapa kecenderungan bentuk jawaban yaitu:

(a) Secara keseluruhan responden dari pengelola program sepakat jika sistem perekrutan yang tidak ketat dan perencanaan yang tidak matang akan berdampak kepada terjadinya kemacetan angsuran pinjaman atau perguliran dana tidak lancar, karena ketidaktepatan dalam penentuan sasaran. Keseluruhan pengelola program sepakat untuk dilakukan pembinaan dan pengarahan secara rutin agar kelancaran angsuran bisa konsisten.

(b) Sebagian besar responden dari pemanfaat program juga sepakat jika dalam sistem seleksi yang tidak ketat akan berdampak kepada terjadinya kemacetan angsuran pinjaman, apalagi kemacetan sebagian bersumber dari oknum aparat desa sendiri. Solusinya adalah di samping dilakukan seleksi secara ketat, juga dilakukan pembinaan sebelum mereka dinyatakan layak mendapatkan dana program.

(6) Berkaitan dengan fungsi dan manfaat keberadaan kelompok pemanfaat (beneficiaries), terdapat beberapa kecenderungan bentuk jawaban yaitu: (a) Sebagian besar pengelola program berpendapat bahwa dampak dari ada atau tidak adanya kelompok pemanfaat program tidak signifikan dikarenakan kelompok tidak difungsikan atau didayagunakan sebagaimana mestinya. (b) Oleh karena itu fungsi keberadaan kelompok harus selalu diarahkan dan dibina melalui berbagai kegiatan seperti kegiatan penyuluhan, pelatihan, pendampingan, dan lain-lain.

Data dikumpulkan melalui beberapa teknik/metode yaitu: metode wawancara mendalam (depth interview), diskusi kelompok terfokus (Focus Group Discussion/FGD), dan kuesioner/angket, observasi; serta dari hasil analisis data baik secara kuantitatif maupun kualitatif. Data tersebut kemudian disintesiskan sebuah model penguatan/pemberdayaan alternatif dalam bentuk Gambar 3 . 


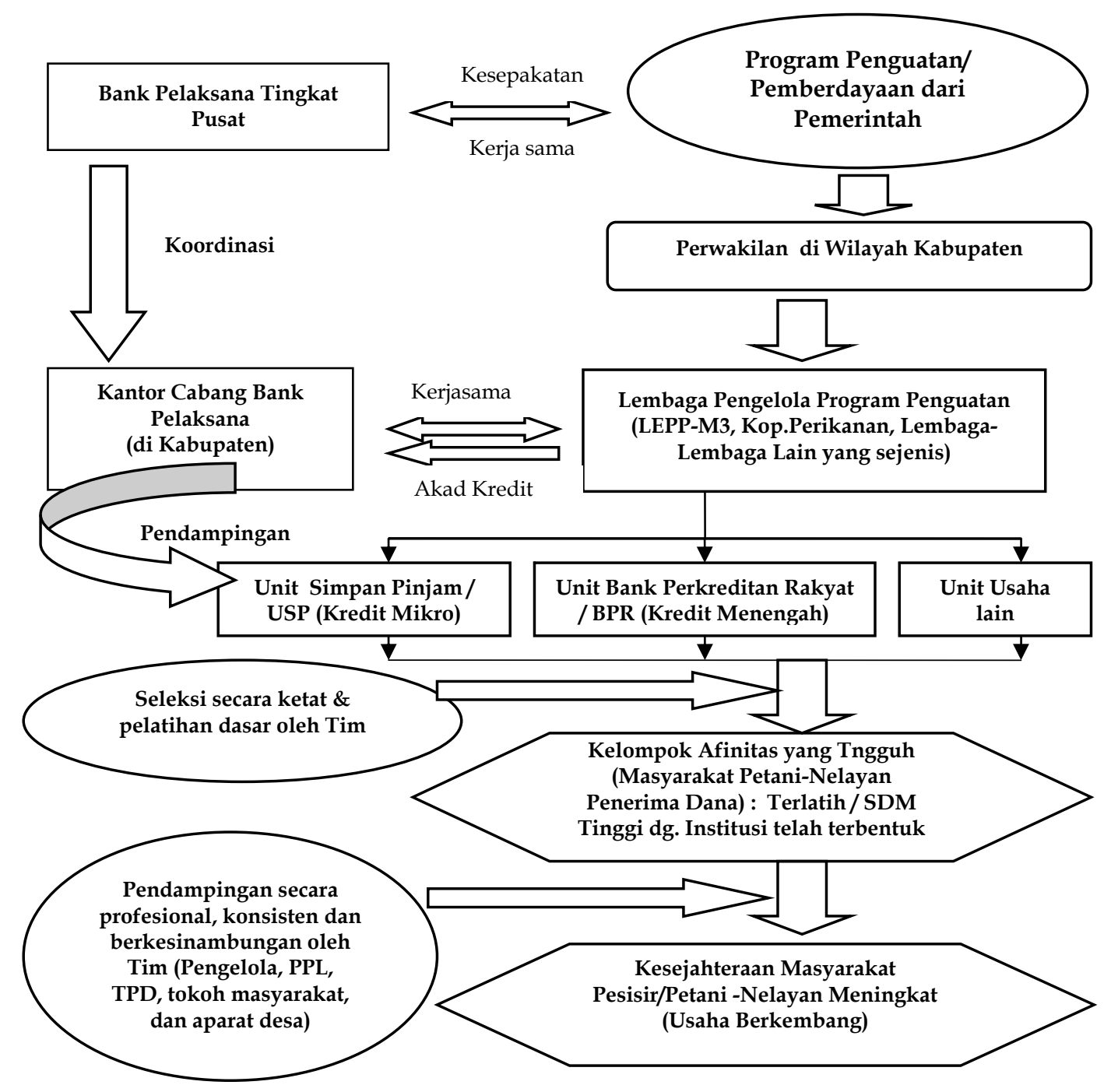

Gambar 3. Model Penguatan/ Pemberdayaan Ekonomi Masyarakat Berbasis Kelompok

\section{SIMPULAN}

Setelah melalui analisis dan pembahasan yang di atas, dapat dikemukakan beberapa kesimpulan sebagai berikut:

Pertama, keberhasilan/keefektifan program, di samping ditentukan oleh baik buruknya peranan para pengelola dan baik buruknya fungsi dari kelompok pemanfaat, juga ditentukan oleh aspek-aspek lain yaitu baik buruknya metode yang digunakan dalam proses seleksi calon penerima bantuan pinjaman dan kurang matangnya perencanaan dalam proses pengucuran dana. Kedua, faktor ketidakmampuan penerima program (beneficiaries) dalam mendayagunakan dana yang mereka terima akan menentukan tinggi rendahnya dampak bantuan program terhadap peningkatan kesejahteraan masyarakat pesisir. Ketiga, analisis Regresi Linear Berganda memberikan temuan bahwa satu faktor yang pengaruhnya tidak signifikan terhadap tingkat kelancaran pembayaran angsuran adalah faktor karakterisitik kelembagaan. Faktorfaktor yang pengaruhnya cukup signifikan adalah tinggi rendahnya komitmen pengelola, tingkat kesesuaian pemberian dana, baik buruknya fungsi kelompok pemanfaat, dukungan moral, dan fluktuasi pendapatan yang mereka terima dari hasil kerja pokok sehari-hari.

Keempat, setelah melalui analisis Model Persamaan Struktural (Structural Equation Modeling/ 
SEM), dapat diidentifikasi konstruk-konstruk atau faktor-faktor yang mempunyai pengaruh signifikan yaitu kemampuan kerja, pengalaman kerja, karakteristik individual, motivasi kerja, dan kinerja (sebagai faktor-faktor internal); dan lingkungan kerja (sebagai faktor eksternal). Kelima, keberhasilan penerapan model penguatan/pemberdayaan ekonomi masyarakat berbasis kelompok (sering diistilahkan dengan kelompok afinitas) yang telah disusun sangat ditentukan oleh komitmen semua elemen stakeholders yang terlibat.

\section{DAFTAR PUSTAKA}

Badan Pusat Statistik. 2010. Penduduk Indonesia Tahun 2010. Jakarta: BPS.

Bank Dunia. 2006. Era Baru dalam Pengentasan Kemiskinan di Indonesia. Jakarta: Gradasi Aksara.

Ghozali, Imam. 2006. Partial Least Square (PLS), Semarang: Badan Penerbit UNDIP.

Danim, Sudarwan. 2004. Motivasi Kepemimpinan $\mathcal{E}$ Efektivitas Kelompok. Jakarta: Penerbit PT. Rineka Cipta.

Deptan. 1996. Pembinaan Petani-Nelayan Kecil: Pedoman Pelaksanaan Program P4K. Jakarta: Departemen Pertanian.

DKP. 2003. PEDUM Program PEMP. Jakarta: Departemen Kelautan dan Perikanan.

Etharina. 2005. Disparitas Pendapatan Antar Daerah di Indonesia. Jurnal Kebijakan Ekonomi, Depok, Universitas Indonesia, ISSN: 1858-2311, Vol.1, No.1, Agustus 2005.

Ghozali, Imam. 2006. Partial Least Squares (PLS). Semarang: Badan Penerbit UNDIP.

Gujarati, Damodar N. 2003. Basic Econometrics. Fourth Edition. New York: Mc Graw-Hill.

Haryani, Sri dan Subkhan, Imam. 2007. Studi Efektivitas Pelaksanaan Proyek Penanggulangan Kemiskinan Perkotaan-Rehabilitasi dan Rekonstruksi Masyarakat dan Permukiman Berbasis Komunitas. Jurnal Ekonomi dan Bisnis Indonesia, Yogyakarta,
Fakultas Ekonomi UGM, Terakreditasi No. 56/DIKTI/KEP./2005, ISSN: 02152487, Volume 22, No.1, Januari 2007.

Kusnadi. 2002. Konflik Sosial Nelayan: Kemiskinan dan Perebutan Sumberdaya Perikanan. Yogyakarta: Penerbit LkiS.

Kusnadi. 2003. Akar Kemiskinan Nelayan. Yogyakarta: LKiS.

Mikkelsen, Britha. 2003. Metode Penelitian Partisipatoris dan Upaya-upaya Pemberdayaan (Terjemahan). Jakarta: Yayasan Obor Indonesia.

Mubyarto. 1997. Pengentasan Kemiskinan Melalui Program IDT. Majalah Ilmiah Pangan, Vol.IX, No.34.

Mubyarto dkk. 1993. Nelayan dan Kemiskinan : Studi Ekonomi Antropologi di Dua Desa Pantai. Jakarta: Rajawali Press.

Njifonjou, Oumarou et.al. 2006. Fisheries CoManagement and Poverty Alleviation in thecontex of the Sustainable Livelihoods Approach: A Case Study in the Fishing Communities of Aby Lagoon", International Journal of Sustainable Development and World Ecology, Vol.13, Edisi 6, 448-459.

Paipita, Indra, $d k k$. 2010. The Impact of Fiscal Policy Toward Economic Performance and Poverty Rate in Indonesia. Bulletin of Monetary Economics and Banking. Jakarta, Bank Indonesia, Accredited: SK. 26/ DIKTI/KEP./2006, ISSN: 1410-8046, Volume 12, Number 4, April 2010.

Joseph W. McGuire, eds., 1974, Contemporare Management: Issues and Viewpont. New Jersey, Englewood Cliffs: Prentice Hall.

Saefuddin, Asep dkk. (Tim Crescent). 2003. Menuju Masyarakat Mandiri (Pengembangan Model Sistem Keterjaminan Sosial). Jakarta: Penerbit PT. Gramedia Pustaka Utama.

Sangaji, Maryam, dkk. 2006. Evaluasi Kredit Mikro Lembaga Swadaya Masyarakat terhadap Pengentasan Kemiskinan. Majalah Ekonomi, Surabaya, Fakultas Ekonomi Universitas Erlangga, Terakreditasi No. 
55/DIKTI/KEP./2005, ISSN: 0854-3038, Tahun XVI, No.3, Desember 2006.

Soesilo, Indroyono dan Budiman. 2002. Iptek untuk Laut Indonesia. Jakarta: Lembaga Informasi dan Studi Pembangunan Indonesia (LISPI).

Suharsimi, dkk. 2005. Model-Model Pemberdayaan Masyarakat. Yogyakarta: Penerbit Pustaka Pesantren.

Sumodiningrat, Gunawan. 1996. Perencanaan Pembangunan dalam Penanggulangan
Kemiskinan. Majalah Ilmiah Prisma, Jakarta, Nomor Khusus 25 Tahun Prisma 1996.

Solimun. 2002. Multivariate Analysis-Structural Equation Modelling (SEM), Lisrel dan Amos. Malang: Penerbit Universitas Negeri Malang.

Yunus, Muhammad. 2007. Bank Kaum Miskin. Tangerang: PT. Cipta Lintas Wacana.

Yustika, Ahmad Erani. 2006. Ekonomi Kelembagaan (Definisi, Teori, dan Strategi). Malang: Penerbit Bayumedia. 